\title{
Assessment of the contribution of microbial activities to tomato growth and yield under an organic production system
}

https://doi.org/10.1515/opag-2019-0063

received July 11, 2019; accepted September 16, 2019

\begin{abstract}
Optimizing microbiological activities in an organic crop production system is crucial to the realization of optimum growth and yield of the crops. Field and pot experiments were conducted to assess soil microbial activities, growth and yield of tomato varieties in response to 4 rates of composted plant and animal residues. The trials were carried out in the Federal University of agriculture, Abeokuta Nigeria, between April 2014 and November 2015. The compost rates were 0, 5, 10 and $20 \mathrm{t} \mathrm{ha}^{-1}$, while the varieties used were Ibadan-improved and Ibadan-local. Fungi population, microbial biomass nitrogen and enzyme activities were significantly higher $(P \leq 0.05)$ at the rhizosphere of the local variety than that of the improved variety. This led to a significantly higher number of branches, plant height, leaf area, number of fruits and less days to maturity in the local variety. Also, growth parameters and tissue $\mathrm{N}$ significantly increased in all compost treatments while dry matter yield and weight of fruits were significantly higher in soil amended with $20 \mathrm{t} \mathrm{ha}^{-1}$. Microbial activities correlated more significantly with growth and yield parameters at 6 weeks after transplanting. It was concluded that microbial activities could be optimized to improve the yield of tomato varieties in an organic production system, through the application of compost, particularly at $20 \mathrm{tha}^{-1}$.
\end{abstract}

Keywords: Compost rates; Tomato varieties; Microbial populations; Microbial biomass; Enzyme activities

\footnotetext{
*Corresponding author: Oluwatoyin A. Babalola, Department of Soil Science and Land Management, Federal University of Agriculture, Abeokuta, Nigeria, Tel: +234 806 6479206, E-mail: babalolaoa@ funaab.edu.ng
}

\section{Introduction}

Crop production is dependent on microorganisms for maximizing soil productivity. This is largely because soil microorganisms perform important functions such as nitrogen fixation, organic matter decomposition, nutrients mineralization and solubilization, exploration, absorption and transfer of nutrients to plants, formation of humus, improvement of soil structure and suppression of pathogenic organisms. Indeed, microorganisms are central to a healthy soil, and functions needed for maximum crop productivity (Altieri 1999; Dick et al. 2001; Garcia-Ruiz et al. 2008). This is more so, in organic cropping systems where microbial mediated decomposition and mineralization of nutrients are central functions in the management of crops (Maeder et al. 2002; Ferreira de Araujo and Jose de Melo 2010). Because synthetic fertilizers and pesticides are avoided, the productivity of the system depends mainly on biological processes. Indeed, organic farming systems rely on sound management of soil organic matter to enhance the chemical, biological and physical properties of the soil (Haynes and Naidu 1998; Altieri 1999; Watson et al. 2002). Organic farming, which is considered as an ecological farming system, was reported to enhance total microbial abundance and activity on a global scale (Lori et al. 2017). Utilization of compost as a soil fertility improvement/sustenance strategy has been widely accepted as a sound practice in organic crop production systems (Ferreira de Araujo and Jose de Melo 2010; Rynk 1992; He et al. 1995). Compost is particularly useful in organic system because the system depends on long term strategies aimed at preventing problems rather than those reacting to problems. Stockdale et al. (2001) suggested that crop rotation could be designed in organic crop production system to improve nutrient cycling and conservation as well as weed, pest and disease control. Indeed, soil amendment with compost enhances the soil organic matter level as well as the chemical, physical and biological conditions of the soil (Haynes and Naidu 1998; Babalola et al. 2012). Soil characteristics like struc- 
ture, water retention and cation exchange capacity are improved due to the use of compost (Acharya et al. 1988; Latif et al. 1992; Haynes and Naidu 1998). Compost is used as mulch (Roe et al. 1993), soil fertility improvement (Roe et al. 1997; Zibilske 2005), it can form part of an integrated weed management program (Grantzau 1987; DeVleeschauwer et al. 1981), suppression of soil borne diseases and improvement in plant resistance to diseases (Reeves et al. 1984; Cook 1986; Hoitnik and Fahey 1986; Sivapalan et al. 1993; Popoola et al. 2011). The composting process and the subsequent gradual decomposition of compost in the soil, leading to plant nutrients releases are mediated mainly by microorganisms. This is because the different genetic and functional activities of the microbial populations have a critical impact on soil functions, based on the fact that microorganisms are driving forces for fundamental metabolic processes involving specific enzymes (Dick 1992; Nannipieri et al. 2003; Barea et al. 2005; Garcia-Ruiz et al. 2008). Microbial interactions are also responsible for key ecological processes, such as biogeochemical cycling of nutrients and organic matter as well as the maintenance of plant health and soil quality (Barea et al. 2004; Garcia-Ruiz, et al. 2008). Furthermore, changes in soil microorganism are often correlated with long-term trends in soil organic matter and fertility and almost all the nutrients in organic fertilizers and green manures must pass through the microbial pool before they are made available for plant uptake (Alexander 1977; Powlson et al. 1987; Maeder et al. 2002). The role of microorganisms in soil ecological functions is particularly important in organic crop production systems, because processes within the system need to be optimized in order to improve productivity. (Maeder et al. 2002). Therefore, the definition of organic farming recognises the complex relationship that exists between different system components and posited that, the sustainability of the system is dependent upon the functioning of a whole integrated and inter-related system (Atkinson and Watson 2000).

In an organic crop production system, the processes leading to soil fertility improvement and sustenance as well as crop resistance to pest and diseases can be optimized through compost amendment; therefore, this study is aimed at evaluating microbial populations and activities in soil amended with 4 rates of compost and assessing their effects on growth and yield of local and improved varieties of tomato. It is hypothesized that increasing rates of compost will increase microbial activities in the soil, and this will lead to higher growth and yield performance of tomato varieties.

\section{Materials and methods}

\subsection{Composting}

Compost was prepared using layers of plant material (Thitonia diversifolia) and poultry manure (deep litter) at a ratio of 3:1 (by volume) in heaps of $1.0 \mathrm{~m}$ by $1.0 \mathrm{~m}$ by $1.5 \mathrm{~m}$. The composting materials were watered to maintain moisture content of 55\% (McKinley et al. 1985) and turned initially 3 weeks after compost set up, and thereafter at 14 days intervals to improve aeration and decomposition of the pile. The temperature in the composting material ranged from $35-60^{\circ} \mathrm{C}$ in the first 3 weeks. Eight weeks was allowed for the composting process to be fully completed and an additional 4 weeks was allowed for curing. At the end of the composting process, analyses revealed that the compost contained $1.5 \%$ nitrogen, $1.2 \%$ phosphorus, $0.7 \%$ potassium, $25 \%$ organic matter and a $\mathrm{C} / \mathrm{N}$ ratio of 9.4 .

\subsection{Pot Experiments}

Two pot experiments were carried out from January to April, and June to September 2014, the two experiments were similarly conducted for the purpose of repetition. The treatments were $2 \times 4$ factorial arranged in Completely Randomized Design (CRD) and replicated 4 times, they consisted of 2 varieties of tomato (Ibadan-improved and Ibadan-local) and 4 rates of compost (0, 5, 10 and 20 tons $\mathrm{ha}^{-1}$ ). The tomato varieties were obtained from National Institute for Horticultural Research (NIHORT), Ibadan.

A soil sample for each experiment was collected at 0-20 cm depth from an experimental field used by Organic Agriculture Project in Tertiary Institutions in Nigeria (OAPTIN) at the Federal University of Agriculture Abeokuta $\left(7^{\circ} 15^{\prime} \mathrm{N}, 3^{\circ} 25^{\prime} \mathrm{E}\right)$ in South Western Nigeria. The soil was air-dried, passed through $4 \mathrm{~mm}$ sieve and $10 \mathrm{~kg}$ was weighed into perforated plastic pots. The soil was sandy (Oxic Paleudulf), neutral in reaction (6.90 in $\mathrm{H}_{2} \mathrm{O}$ ), with low contents of nitrogen $(0.09 \%)$, organic matter $(2.83 \%)$ and effective cation exchange capacity $\left(2.35 \mathrm{Cmol} \mathrm{kg}^{-1}\right)$, moderate in Bray 1 available phosphorus $\left(9.24 \mathrm{mg} \mathrm{kg}^{-1}\right)$ but high in potassium $\left(0.51 \mathrm{Cmol} \mathrm{kg}^{-1}\right)$. Two weeks before transplanting, the 3 compost rates were applied to their corresponding pots, mixed thoroughly with soil and watered to field capacity. Two 3-weeks old tomato seedlings were transplanted into each pot, one of the seedlings was monitored until 6 weeks after transplanting (WAT) and then harvested for the determination of dry matter yield and tissue concentration of P and N (Murphy and Riley, 1962; 
Juo et al. 1974; Bremner 1996), while the other plant was left until fruiting. Other data collected at 6 WAT were plant height, number of branches, stem girth, number of leaves and leaf area. The yield data collected include, days to flowering, days to fruiting, number and weight of fruits.

\subsection{Soil analysis}

Moist rhizosphere soil samples were collected from the pot experiments at 3 sampling periods; 2 weeks after compost application but before tomato transplanting (BT), 6 weeks after transplanting (6 WAT) and at harvest (HVT). Total microbial and fungi populations were estimated using the dilution plate count method (Zuberer 1994), population of Nitrosomonas sp was determined by Most Probable Number method according to Cochran (1950) and Nitrobacter population was estimated using the Griess-Ilosvay reagent after incubation in nitrite-calcium carbonate solution. Microbial biomass carbon, nitrogen and phosphorus were determined by the chloroform fumigation-incubation technique (Jenkinson and Powlson, 1976; Anderson and Domsch 1978) as modified by Anderson and Ingram (1993). Cellulase and amylase activities were estimated using the method described by Takeda and Hizukuri (1969) and protease was estimated using the method of Beralseld (1955). Total nitrogen was measured using the micro-kjeldahl method (Bremner 1996), ammonium and nitrate nitrogen were determined by a colorimetric method based on Berthelot's reaction (Sommers et al. 1992), available phosphorus by Bray 1 method (Bray and Kutz 1945) and $\mathrm{P}$ in solution was determined by the molybdate colorimetric method and organic carbon was determined by Walkley-Black dichromate method (Nelson and Summers 1996).

\subsection{Field experiment}

Two experiments were conducted consecutively in the late seasons of 2014 (August-October) and 2015 (September-November) on the OAPTIN experimental field, located at the Federal University of Agriculture, Abeokuta, Nigeria $\left(7^{\circ} 15^{\prime}\right.$ $\left.\mathrm{N}, 3^{\circ} 25^{\prime} \mathrm{N}\right)$. The experiments were $2 \times 3$ factorial, arranged in randomized completely block design with three replicates. The treatments were two determinate varieties of tomato (Ibadan-improved and Ibadan-local) and 3 rates of compost $\left(0,10\right.$ and $\left.20 \mathrm{tha}^{-1}\right)$. The field was mechanically ploughed, harrowed and differentiated into plots of $4 \times 5$ $\mathrm{m}$. The three rates of compost were manually broadcasted to their corresponding plots and worked thoroughly into the soil at two weeks before tomato transplanting. Tomato seedlings were raised on rich loamy soil, prepared with fine tilth and allowed to grow for 3 weeks; when at least 3 true leaves were observed, and the plant height was up to $15 \mathrm{~cm}$. The seedlings were transplanted at spacings of 60 x $30 \mathrm{~cm}$ giving a plant population of 39,000 ha-1. Thereafter, the number of branches, plant height and dry matter yield were determined at 6 WAT and number and weight of fruits were determined after harvest.

\subsection{Statistical analysis}

Greenhouse data on soil microbiological and chemical properties, nutrient concentration, growth and yield of tomato varieties were analysed as a factorial completely randomized design and field data on tomato growth and yield characteristics were analysed as factorial randomized completely blocked design using the SAS (1989) procedure and where significant at up to $5 \%$ probability. The means were separated using the Least Significant Difference (LSD). Correlation analysis between the growth and yield characteristics and microbial parameters was achieved using the formulae suggested by Wahua (1999).

\section{Results}

\subsection{Response of soil microbial populations to treatments}

Microbial populations (bacteria and fungi) were significantly higher in the rhizosphere of the local variety (Tables 1). Pots amended with compost at 5 ton ha ${ }^{-1}$ and control had similar values of microbial populations in the first pot experiment, but in the second pot experiment, significantly higher values of microbial populations were recorded in all compost amended pots compared with the control, and pots amended with $20 \mathrm{t} \mathrm{ha}^{-1}$ of compost sustained the highest microbial populations throughout the cropping periods. This trend was observed in the main effect of compost as well as in the interaction between compost and variety (Table 1). It was also observed that increasing the compost rate from 5 to $10 \mathrm{tha}^{-1}$ and from 10 to $20 \mathrm{tha}^{-1}$ led to significant increases in fungal and bacteria populations. 
Table 1: Soil bacterial $\left(10^{5} \mathrm{cfu} \mathrm{g}^{-1} \mathrm{soil}\right)$ and fungal $\left(10^{4} \mathrm{cfu} \mathrm{g}^{-1} \mathrm{soil}\right)$ populations in two pot experiments with 4 rates of compost and to 2 tomato varieties

\begin{tabular}{|c|c|c|c|c|c|c|c|c|c|c|c|c|}
\hline \multirow{3}{*}{$\begin{array}{l}\text { Treatment } \\
\text { Varieties }\end{array}$} & \multicolumn{6}{|c|}{ First experiment } & \multicolumn{6}{|c|}{ Second experiment } \\
\hline & \multicolumn{2}{|c|}{ Bacteria } & \multicolumn{2}{|l|}{ Fungi } & \multicolumn{2}{|l|}{ NB } & \multicolumn{3}{|c|}{ Bacteria } & \multicolumn{3}{|l|}{ Fungi } \\
\hline & BT & HVT & BT & HVT & BT & HVT & BT & 6WAT & HVT & BT & 6WAT & HVT \\
\hline Local & NA & $15.1^{\mathrm{a}}$ & NA & $6.7^{\mathrm{a}}$ & NA & $0.77^{a}$ & NA & 12.5 & 5.6 & NA & $9.7^{\mathrm{a}}$ & 5.6 \\
\hline Improved & NA & $12.5^{\mathrm{a}}$ & NA & $6.0^{\mathrm{b}}$ & NA & $0.62^{\mathrm{b}}$ & NA & 11.3 & 5.2 & NA & $7.4^{b}$ & 5.2 \\
\hline \multicolumn{13}{|c|}{ Compost $\left(\mathrm{t} \mathrm{ha}^{-1}\right)$} \\
\hline 0 & $14.2^{\mathrm{b}}$ & 14.5 & $6.0^{\mathrm{b}}$ & 6.7 & $1.00^{c}$ & $0.41^{c}$ & $10.6^{c}$ & $6.5^{c}$ & $4.0_{c}$ & $4.5^{c}$ & $4.5^{c}$ & $4.0^{c}$ \\
\hline 5 & $14.4^{\mathrm{b}}$ & 12.9 & $6.3^{\mathrm{b}}$ & 5.0 & $0.88^{c}$ & $0.45^{c}$ & $16.8^{c}$ & $11.1^{\mathrm{b}}$ & $5.0^{\mathrm{b}}$ & $7.2^{\mathrm{b}}$ & $8.0^{\mathrm{b}}$ & $5.0^{\mathrm{b}}$ \\
\hline 10 & $16.9^{a}$ & 13.8 & $6.2^{\mathrm{b}}$ & 6.7 & $1.28^{\mathrm{b}}$ & $0.70^{\mathrm{b}}$ & $19.7^{b}$ & $14.5^{\mathrm{ab}}$ & $5.8^{\mathrm{b}}$ & $7.8^{\mathrm{b}}$ & $10.5^{\mathrm{a}}$ & $5.8^{\mathrm{b}}$ \\
\hline 20 & $16.9^{\mathrm{a}}$ & 14.0 & $7.3^{\mathrm{a}}$ & 7.2 & $1.47^{\mathrm{a}}$ & $1.03^{\mathrm{a}}$ & $22.1^{\mathrm{a}}$ & $15.5^{\mathrm{a}}$ & $6.7^{\mathrm{a}}$ & $15.0^{\mathrm{a}}$ & $11.2^{\mathrm{a}}$ & $6.7^{\mathrm{a}}$ \\
\hline \multicolumn{13}{|c|}{ Compost x variety } \\
\hline \multicolumn{13}{|l|}{ Local } \\
\hline 0 & 15.0 & $13.7^{c}$ & 6.3 & $4.0^{c}$ & $1.5^{c}$ & $0.70^{\mathrm{b}}$ & $10.5^{\mathrm{e}}$ & $4.9^{c}$ & $4.3^{\mathrm{ef}}$ & $5.0^{\text {cd }}$ & $4.7^{\mathrm{d}}$ & $4.3^{e f}$ \\
\hline 5 & 14.0 & $14.1^{\mathrm{c}}$ & 7.0 & $6.7^{\mathrm{ab}}$ & $1.8^{\mathrm{b}}$ & $0.40^{c}$ & $17.0^{c}$ & $13.2^{\mathrm{ab}}$ & $5.3^{\text {cde }}$ & $7.7^{c}$ & $9.0^{c}$ & $5.3^{\text {cde }}$ \\
\hline 10 & 13.0 & $15.3 b$ & 6.7 & $6.7^{\mathrm{ab}}$ & $1.9^{\mathrm{b}}$ & $0.80^{\mathrm{b}}$ & $20.5^{b}$ & $15.2^{\mathrm{a}}$ & $6.1^{\mathrm{abc}}$ & $7.3^{c}$ & $12.3^{\mathrm{ab}}$ & $6.1^{\mathrm{abc}}$ \\
\hline 20 & 13.0 & $17.2^{\mathrm{a}}$ & 6.7 & $6.7^{\mathrm{ab}}$ & $2.0^{\mathrm{a}}$ & $1.17^{\mathrm{a}}$ & $22.3^{\mathrm{a}}$ & $16.5^{\mathrm{a}}$ & $6.9^{\mathrm{a}}$ & $17.0^{\mathrm{a}}$ & $12.7^{\mathrm{a}}$ & $6.9^{\mathrm{a}}$ \\
\hline \multicolumn{13}{|l|}{ Improved } \\
\hline 0 & 13.4 & $11.8^{\mathrm{d}}$ & 8.0 & $6.7^{\mathrm{ab}}$ & $1.50^{c}$ & $0.53^{\mathrm{bc}}$ & $10.5^{\mathrm{e}}$ & $7.6^{c}$ & $3.8^{f}$ & $4.0^{\mathrm{d}}$ & $4.3^{d}$ & $3.8^{\mathrm{f}}$ \\
\hline 5 & 14.9 & $10.0^{\mathrm{d}}$ & 5.7 & $6.0^{\mathrm{b}}$ & $1.37^{c}$ & $0.43^{c}$ & $16.5^{d}$ & $9.0 b^{c}$ & $4.7^{\mathrm{def}}$ & $6.7^{\mathrm{cd}}$ & $7.0^{\mathrm{cd}}$ & $4.7^{\mathrm{def}}$ \\
\hline 10 & 20.8 & $13.9^{c}$ & 5.7 & $6.7^{\mathrm{ab}}$ & $1.9^{\mathrm{b}}$ & $0.60^{\mathrm{b}}$ & $18.9^{c}$ & $13.8^{\mathrm{ab}}$ & $5.6 b^{c d}$ & $8.3^{c}$ & $8.7^{c}$ & $5.6 b^{c d}$ \\
\hline 20 & 20.7 & $13.9^{c}$ & 8.0 & $7.7^{\mathrm{a}}$ & $2.27^{\mathrm{a}}$ & $0.90^{\mathrm{b}}$ & $22.0^{\mathrm{a}}$ & $14.6^{a}$ & $6.6 a^{b}$ & $13.0^{\mathrm{b}}$ & $9.7^{\mathrm{bc}}$ & $6.6 a^{b}$ \\
\hline
\end{tabular}

Values followed by different alphabets are statistically different at $\mathrm{P} \leq 0.05, \mathrm{BT}=$ before transplanting, at the end of 2 weeks compost/soil incubation, 6 WAT $=6$ weeks after transplanting, HVT= harvest

$\mathrm{NA}=$ Not applicable as plants were not yet transplanted, $\mathrm{NB}=$ Count of nitrifying bacteria.

\subsection{Response of microbial biomass N, P and C to treatments}

Generally, microbial biomass N, P and C were statistically similar in the rhizosphere of the two varieties. Only at 6 WAT was microbial biomass $\mathrm{N}$ observed to be higher in the rhizosphere of the local variety compared with the improved variety (Table 2). High reduction in microbial biomass $\mathrm{N}$ as a result of tomato cropping was observed in the 2 pot experiments. In the second experiment, the values of microbial biomass $\mathrm{N}$ recorded for compost amendments, ranged from 110.3-130.3 before transplanting but dropped to 0.013-0.018 at 6 WAT and 0.008-0.013 at harvest. Although reductions were also observed in microbial biomass $\mathrm{P}$ and $\mathrm{C}$, they were not as high as in N. Moreover, soil in pots, which were amended with compost, had higher microbial biomass nutrients than in unamended control pots. Also, those amended with $20 \mathrm{t} \mathrm{ha}^{-1}$ compost had higher microbial biomass N, P and C than those with lower levels of compost (Table 2). It was also observed that comparatively, pots with $20 \mathrm{t} \mathrm{ha}^{-1}$ compost and sown to the local variety consistently had the maximum values of microbial biomass $\mathrm{N}, \mathrm{P}$ and $\mathrm{C}$.

\subsection{Response of enzyme activities to treatments}

Activities of cellulases, amylases and protease, as presented in Table 3, revealed that cellulase and protease activities were higher at the rhizosphere of the local variety compared with the improved variety. Furthermore, slight and gradual reductions were observed in the values at different rates of compost application, as tomato cropping progressed, the initial range of cellulase was reduced by $12.36-20.7 \%{ }^{1}$ at harvest. Amylase was reduced by $12.24-19.86 \%$ and protease by $6.95-9.48 \%$ (Table 4). Moreover, soil from pots amended with compost had significantly higher enzyme activities compared with soil in unamended control pots and soil amended with $20 \mathrm{t} \mathrm{ha}^{-1}$ of compost showed higher activities of cellulase, amylase and protease than those amended with $5 \mathrm{t} \mathrm{ha}^{-1}$. It was also observed that enzyme activities were comparable or similar in soils amended with 10 and $20 \mathrm{t} \mathrm{ha}^{-1}$, except for samples taken before transplanting, when $20 \mathrm{t} \mathrm{ha}^{-1}$ had higher activities of cellulase and amylase than $10 \mathrm{t} \mathrm{ha}^{-1}$. This trend was also observed in the interaction of compost with the two tomato varieties (Table 3). 


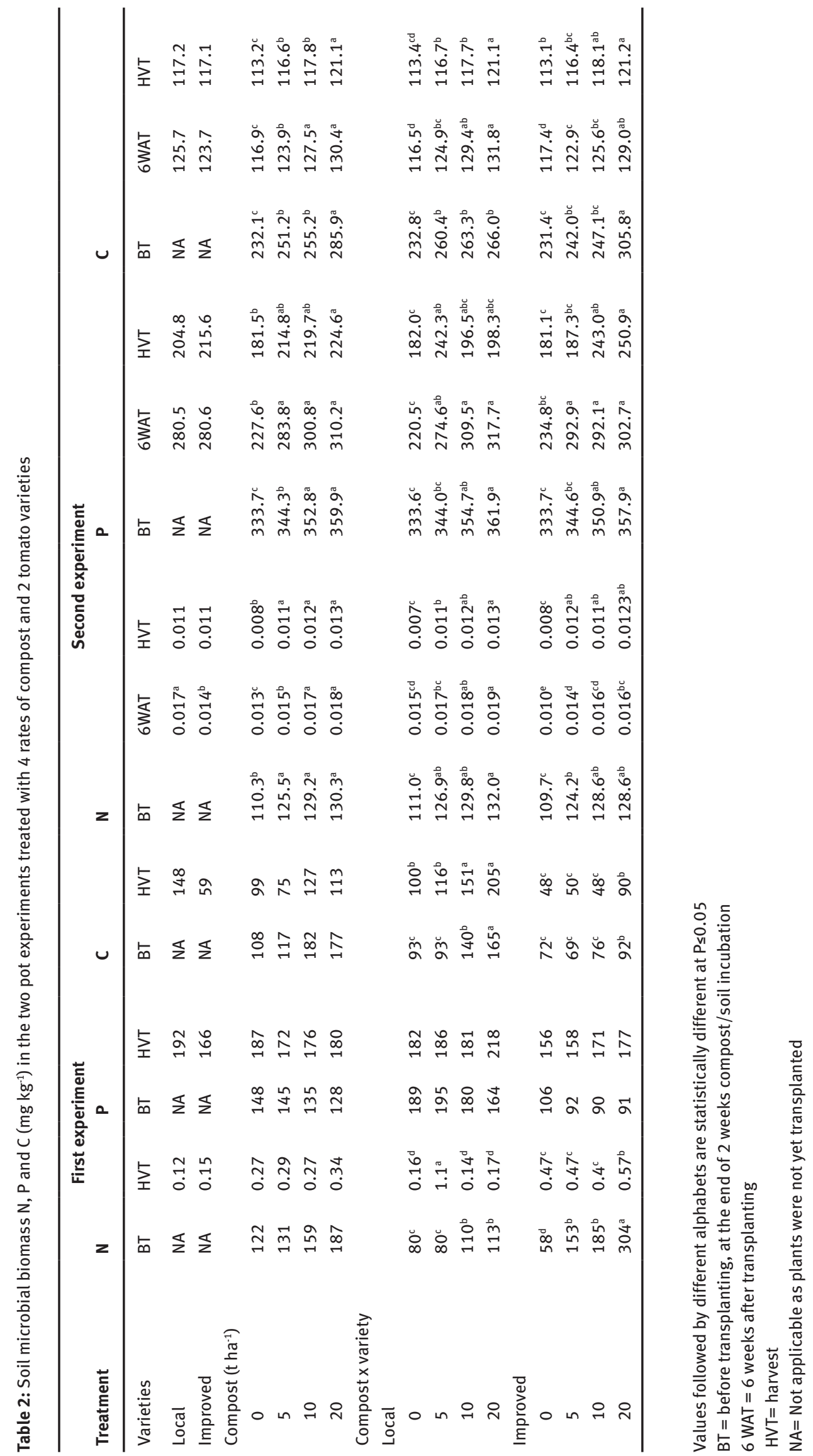


Table 3: Soil cellulase, amylase and protease activities $\left(\mu \mathrm{g} \mathrm{g}^{-1}\right)$ at 3 sampling periods in the second pot experiment amended with 4 rates of compost and sown to 2 tomato varieties

\begin{tabular}{|c|c|c|c|c|c|c|c|c|c|}
\hline Treatment & Cellulase & & & Amylase & & & Protease & & \\
\hline Varieties & BT & 6 WAT & HVT & BT & 6 WAT & HVT & BT & 6 WAT & HVT \\
\hline Local & NA & $0.1259^{\mathrm{a}}$ & 0.1168 & NA & 0.1175 & 0.1114 & NA & $0.1219^{\mathrm{a}}$ & 0.1068 \\
\hline Improved & NA & $0.1249^{b}$ & 0.1185 & NA & 0.1157 & 0.1123 & NA & $0.1171^{b}$ & 0.1094 \\
\hline \multicolumn{10}{|c|}{ Compost $\left(\mathrm{t} \mathrm{ha}^{-1}\right)$} \\
\hline 0 & $0.1238^{d}$ & $0.1227^{c}$ & $0.1085^{c}$ & $0.1217^{d}$ & $0.1130^{\mathrm{b}}$ & $0.1068^{c}$ & $0.1107^{c}$ & $0.1133^{c}$ & $0.1030^{c}$ \\
\hline 5 & $0.1380^{c}$ & $0.1250^{\mathrm{b}}$ & $0.1188^{b}$ & $0.1378^{c}$ & $0.1165^{\mathrm{a}}$ & $0.1118^{\mathrm{b}}$ & $0.1192^{\mathrm{b}}$ & $0.1190^{\mathrm{b}}$ & $0.1072^{\mathrm{bc}}$ \\
\hline 10 & $0.1493^{b}$ & $0.1265^{\mathrm{a}}$ & $0.1205^{\mathrm{ab}}$ & $0.1405^{b}$ & $0.1175^{\mathrm{a}}$ & $0.1137^{\mathrm{ab}}$ & $0.1218^{\mathrm{ab}}$ & $0.1218^{\mathrm{ab}}$ & $0.1095^{\mathrm{ab}}$ \\
\hline 20 & $0.1542^{\mathrm{a}}$ & $0.1275^{\mathrm{a}}$ & $0.1222^{\mathrm{a}}$ & $0.1435^{\mathrm{a}}$ & $0.1195^{\mathrm{a}}$ & $0.1150^{\mathrm{a}}$ & $0.1245^{\mathrm{a}}$ & $0.1283^{\mathrm{ab}}$ & $0.1127^{a}$ \\
\hline \multicolumn{10}{|c|}{ Compost $\mathrm{x}$ variety } \\
\hline \multicolumn{10}{|l|}{ Local } \\
\hline 0 & $0.1233^{\mathrm{e}}$ & $0.1137^{c d}$ & $0.1043^{c}$ & $0.1220^{\mathrm{e}}$ & $0.1136^{\mathrm{e}}$ & $0.1043^{c}$ & $0.1103^{d}$ & $0.1080^{c}$ & $0.1030^{\mathrm{b}}$ \\
\hline 5 & $0.1380^{d}$ & $0.1173^{\mathrm{abc}}$ & $0.1120^{\mathrm{ab}}$ & $0.1383^{d}$ & $0.1220^{\mathrm{abc}}$ & $0.1120^{\mathrm{ab}}$ & $0.1203^{b c}$ & $0.1170^{\mathrm{b}}$ & $0.1050^{b}$ \\
\hline 10 & $0.1503^{b c}$ & $0.1187^{\mathrm{ab}}$ & $0.1443^{\mathrm{a}}$ & $0.1413^{\mathrm{bc}}$ & $0.1250^{\mathrm{ab}}$ & $0.1143^{\mathrm{a}}$ & $0.1223^{a b c}$ & $0.1200^{\mathrm{ab}}$ & $0.1073^{a b}$ \\
\hline 20 & $0.1550^{\mathrm{a}}$ & $0.1207^{a}$ & $0.1150^{\mathrm{a}}$ & $0.1443^{a}$ & $0.1270^{\mathrm{a}}$ & $0.1150^{\mathrm{a}}$ & $0.1250^{\mathrm{a}}$ & $0.1220^{\mathrm{a}}$ & $0.1117^{a}$ \\
\hline \multicolumn{10}{|l|}{ Improved } \\
\hline 0 & $0.1243^{e}$ & $0.1123^{d}$ & $0.1093^{c}$ & $0.1213^{e}$ & $0.1130^{\mathrm{e}}$ & $0.1093^{c}$ & $0.1110^{d}$ & $0.1090^{c}$ & $0.1030^{b}$ \\
\hline 5 & $0.1380^{d}$ & $0.1157^{c d}$ & $0.1117^{\mathrm{ab}}$ & $0.1373^{d}$ & $0.1160^{\text {de }}$ & $0.1117^{\mathrm{ab}}$ & $0.1180^{c}$ & $0.1207^{\mathrm{ab}}$ & $0.1093^{\mathrm{ab}}$ \\
\hline 10 & $0.1483^{c}$ & $0.1163^{\mathrm{abcd}}$ & $0.1130^{\mathrm{ab}}$ & $0.1397^{c d}$ & $0.1187^{\text {cde }}$ & $0.1130^{\mathrm{ab}}$ & $0.1213^{\mathrm{abc}}$ & $0.1210^{\mathrm{ab}}$ & $0.1117^{\mathrm{a}}$ \\
\hline 20 & $0.1533^{\mathrm{ab}}$ & $0.1183^{\mathrm{abc}}$ & $0.1150^{a}$ & $0.1427^{\mathrm{ab}}$ & $0.1207^{\mathrm{bcd}}$ & $0.1150^{\mathrm{a}}$ & $0.1240^{\mathrm{ab}}$ & $0.1223^{\mathrm{a}}$ & $0.1137^{a}$ \\
\hline
\end{tabular}

Values followed by different alphabets are statistically different at $\mathrm{P} \leq 0.05$ $\mathrm{BT}=$ before transplanting, at the end of 2 weeks compost/soil incubation 6 WAT $=6$ weeks after transplanting HVT= harvest

$\mathrm{NA}=$ Not applicable as plants were not yet transplanted

\subsection{Response of soil N, $\mathrm{P}$ and organic carbon to treatments}

Table 4 reveals that soil $\mathrm{N}$ and organic carbon were statistically similar in the rhizosphere of the two tomato varieties at harvest, but insignificantly higher in the rhizosphere of the local variety. However, soil P was significantly higher in the rhizosphere of the local variety compared with the improved variety. It was also revealed that nitrate and ammonium nitrogen were insignificantly higher at 3 WAT and significantly higher at 6 WAT at the rhizosphere of the local variety compared with the improved variety. All the nutrients were significantly higher in compost amended pots compared with the control pots. Amendment of soil with $20 \mathrm{t} \mathrm{ha}^{-1}$ of compost consistently gave higher total $\mathrm{N}, \mathrm{NH}_{4}-\mathrm{N}, \mathrm{NO}_{3}-\mathrm{N}, \mathrm{P}$ and organic carbon than amendment with $5 \mathrm{t} \mathrm{ha}^{-1}$. This trend was also observed in the interaction of compost with the 2 varieties, but the trend was more consistent in the local variety (Table 4).

\subsection{Response of growth characteristics to treatments}

Observation from the pot and field experiments indicated that the local variety had a more vigorous growth than the improved variety under an organic production system. Table 5 shows that in the first pot experiment, all the measured growth parameters were insignificantly higher in the local variety. However, in the second pot experiment, values recorded for the number of branches, plant height and leaf area were significantly higher in the local variety. Furthermore, in the two experiments, the number of branches and plant height were significantly higher in pots, which were amended with 20 t ha $^{-1}$ compost compared with the other treatments, but in the second pot experiment, numbers of leaves and leaf area were also significantly higher in pots amended with compost compared with the control pots, while stem girth was insignificantly higher in compost amended pots compared with control in the 2 pot experiments. Observation of the inter- 
Table 4: Combined analysis of soil chemical properties at 2 sampling periods in pot experiments amended with 4 rates of compost and 2 tomato varieties

\begin{tabular}{|c|c|c|c|c|c|c|c|c|c|c|}
\hline \multirow{2}{*}{$\begin{array}{l}\text { Treatment } \\
\text { Varieties }\end{array}$} & \multicolumn{2}{|c|}{ Nitrogen (\%) } & \multicolumn{2}{|c|}{ Phosphorus (mg kg-1) } & \multicolumn{2}{|c|}{ Organic carbon (\%) } & \multicolumn{2}{|c|}{ Soil $\mathrm{NH}_{4}-\mathrm{N}(\%)$} & \multicolumn{2}{|c|}{$\mathrm{NO}_{3}-\mathrm{N}(\%)$} \\
\hline & BT & HVT & BT & HVT & BT & HVT & 3WAT & 6WAT & 3WAT & 6WAT \\
\hline Local & NA & 0.0264 & NA & $7.42^{\mathrm{a}}$ & NA & 0.3632 & 0.121 & $0.176^{\mathrm{a}}$ & 0.115 & $0.085^{\circ}$ \\
\hline Improved & NA & 0.0199 & NA & $6.63^{b}$ & NA & 0.3467 & 0.084 & $0.052^{\mathrm{b}}$ & 0.061 & $0.068^{b}$ \\
\hline \multicolumn{11}{|c|}{ Compost $\left(\mathrm{t} \mathrm{ha}^{-1}\right)$} \\
\hline 0 & $0.1070^{c}$ & 0.0090 & $9.57^{d}$ & $6.06^{b}$ & $12.09^{d}$ & $0.2380^{d}$ & 0.076 & $0.076^{\mathrm{b}}$ & $0.070^{\mathrm{b}}$ & $0.063^{\circ}$ \\
\hline 5 & $0.1233^{b}$ & 0.0262 & $11.20^{c}$ & $6.98^{\mathrm{a}}$ & $15.52^{c}$ & $0.3433^{c}$ & 0.095 & $0.127^{\mathrm{a}}$ & $0.049^{b}$ & $0.073^{b}$ \\
\hline 10 & $0.1277^{\mathrm{ab}}$ & 0.0273 & $13.26^{\mathrm{b}}$ & $7.39^{a}$ & $18.43^{b}$ & $0.3995^{b}$ & 0.132 & $0.121^{\mathrm{a}}$ & $0.065^{b}$ & $0.062^{b}$ \\
\hline 20 & $0.1313^{\mathrm{a}}$ & 0.0302 & $15.85^{\mathrm{a}}$ & $7.66^{\mathrm{a}}$ & $21.50^{\mathrm{a}}$ & $0.4390^{\mathrm{a}}$ & 0.107 & $0.134^{\mathrm{a}}$ & $0.168^{\mathrm{a}}$ & $0.111^{\mathrm{a}}$ \\
\hline \multicolumn{11}{|c|}{ Compost $\mathrm{x}$ variety } \\
\hline \multicolumn{11}{|l|}{ Local } \\
\hline 0 & $0.1073^{c}$ & $0.0050^{\mathrm{b}}$ & $9.62^{\mathrm{g}}$ & $6.72^{\mathrm{b}}$ & $12.07^{e}$ & $0.2367^{e}$ & $0.031^{c}$ & $0.104^{b}$ & $0.057^{c}$ & $0.036^{\circ}$ \\
\hline 5 & $0.1247^{b}$ & $0.0090^{\mathrm{b}}$ & $11.70^{\mathrm{e}}$ & $7.31^{\mathrm{ab}}$ & $16.40^{c}$ & $0.3667^{c}$ & $0.077^{b}$ & $0.184^{\mathrm{a}}$ & $0.055^{c}$ & $0.088^{\circ}$ \\
\hline 10 & $0.1287^{\mathrm{ab}}$ & $0.0443^{a}$ & $13.93^{c}$ & $7.74^{\mathrm{ab}}$ & $19.90^{\mathrm{b}}$ & $0.4012^{b c}$ & $0.10^{\mathrm{ab}}$ & $0.197^{\mathrm{a}}$ & $0.064^{c}$ & $0.10^{b}$ \\
\hline 20 & $0.1340^{\mathrm{a}}$ & $0.0473^{a}$ & $16.11^{\mathrm{a}}$ & $7.93^{a}$ & $23.27^{\mathrm{a}}$ & $0.4480^{\mathrm{a}}$ & $0.130^{\mathrm{a}}$ & $0.220^{\mathrm{a}}$ & $0.283^{\mathrm{a}}$ & $0.117^{b}$ \\
\hline \multicolumn{11}{|l|}{ Improved } \\
\hline 0 & $0.1067^{c}$ & $0.0090^{\mathrm{b}}$ & $9.52^{\mathrm{g}}$ & $5.41^{c}$ & $12.10^{\mathrm{e}}$ & $0.2393^{\mathrm{e}}$ & $0.031^{c}$ & $0.048^{b}$ & $0.053^{c}$ & $0.029^{\circ}$ \\
\hline 5 & $0.2200^{\mathrm{b}}$ & $0.0130^{b}$ & $10.70^{f}$ & $6.66^{b}$ & $14.63^{d}$ & $0.3200^{d}$ & $0.077^{\mathrm{b}}$ & $0.048^{b}$ & $0.043^{c}$ & $0.023^{\circ}$ \\
\hline 10 & $0.1267^{a b}$ & $0.0103^{b}$ & $12.60^{d}$ & $7.05^{b}$ & $16.97^{c}$ & $0.3973^{b c}$ & $0.10^{\mathrm{ab}}$ & $0.044^{\mathrm{b}}$ & $0.065^{c}$ & $0.037^{\circ}$ \\
\hline 20 & $0.1287^{\mathrm{ab}}$ & $0.0473^{a}$ & $15.60^{\mathrm{b}}$ & $7.40^{\mathrm{ab}}$ & $19.73^{b}$ & $0.4300^{\mathrm{ab}}$ & $0.130^{\mathrm{a}}$ & $0.069^{b}$ & $0.082^{\mathrm{b}}$ & $0.185^{\circ}$ \\
\hline
\end{tabular}

Values followed by different alphabets are statistically different at $\mathrm{P} \leq 0.05$

BT = before transplanting, at the end of 2 weeks compost/soil incubation

HVT= harvest

WAT $=$ Weeks after transplanting

Table 5: Nutrient concentrations and growth characteristics of 2 tomato varieties in pot experiments amended with 4 rates of compost

\begin{tabular}{|c|c|c|c|c|c|c|c|c|c|}
\hline \multirow[b]{2}{*}{ Treatment } & \multicolumn{4}{|c|}{ First pot experiment } & \multicolumn{5}{|c|}{ Second pot experiment } \\
\hline & N (\%) & $\mathrm{P}(\%)$ & $\begin{array}{l}\text { No of } \\
\text { branches }\end{array}$ & $\begin{array}{l}\text { Plant } \\
\text { height }(\mathrm{cm})\end{array}$ & No of & sNo of leaves & $\begin{array}{l}\text { Stem girth } \\
(\mathrm{cm})\end{array}$ & $\begin{array}{l}\text { Plant height } \\
(\mathrm{cm})\end{array}$ & Leaf area $\left(\mathrm{cm}^{2}\right)$ \\
\hline \multicolumn{10}{|l|}{ Varieties } \\
\hline Local & 8.66 & 4.19 & 23 & 77.5 & $36^{a}$ & 310 & 3.4 & $86.7^{a}$ & $72.1^{a}$ \\
\hline Improved & 9.22 & 4.30 & 21 & 71.9 & $25^{b}$ & 256 & 3.0 & $67.2^{b}$ & $58.2^{b}$ \\
\hline Compost $\left(\mathrm{t} \mathrm{ha}^{-1}\right)$ & & & & & $19^{b}$ & & & & \\
\hline 0 & $8.30^{c}$ & 4.27 & $19^{b}$ & $75.0^{\mathrm{b}}$ & & $158^{b}$ & 2.9 & $65.0^{c}$ & $52.1^{b}$ \\
\hline 5 & $9.10^{\mathrm{ab}}$ & 4.09 & $21^{b}$ & $68.0^{\mathrm{b}}$ & $35^{a}$ & $334^{\mathrm{a}}$ & 3.4 & $87.0^{\mathrm{a}}$ & $64.0^{\mathrm{ab}}$ \\
\hline 10 & $9.55^{\mathrm{a}}$ & 4.29 & $22^{b}$ & $69.4^{\mathrm{b}}$ & $34^{\mathrm{a}}$ & $310^{a}$ & 3.4 & $71.5^{\mathrm{bc}}$ & $73.1^{\mathrm{a}}$ \\
\hline 20 & $9.10^{\mathrm{ab}}$ & 4.33 & $27^{b}$ & $84.9^{a}$ & $34^{\mathrm{a}}$ & $331^{a}$ & 3.3 & $84.5^{\mathrm{ab}}$ & $71.5^{\mathrm{a}}$ \\
\hline \multicolumn{10}{|l|}{ Compost x Variety } \\
\hline \multicolumn{10}{|l|}{ Local } \\
\hline 0 & $7.73^{\mathrm{c}}$ & $4.02^{b}$ & 20 & 72.7 & $25^{\mathrm{ab}}$ & $206^{\mathrm{ab}}$ & $3.2^{\mathrm{ab}}$ & $81.0^{a b c}$ & $59.6^{a b}$ \\
\hline 5 & $8.80^{\mathrm{ab}}$ & $4.14^{\mathrm{ab}}$ & 22 & 76.0 & $41^{\mathrm{a}}$ & $364^{a}$ & $3.0^{\mathrm{ab}}$ & $96.3^{a}$ & $70.2^{\mathrm{ab}}$ \\
\hline 10 & $9.57^{a}$ & $4.35^{\mathrm{ab}}$ & 26 & 78.0 & $37^{a}$ & $325^{a}$ & $3.6^{a}$ & $94.7^{\mathrm{ab}}$ & $77.4^{\mathrm{a}}$ \\
\hline 20 & $8.87^{\mathrm{ab}}$ & $4.25^{\mathrm{ab}}$ & 24 & 83.3 & $39^{a}$ & $346^{a}$ & $3.5^{\mathrm{a}}$ & $95.0^{\mathrm{ab}}$ & $81.2^{\mathrm{a}}$ \\
\hline \multicolumn{10}{|l|}{ Improved } \\
\hline 0 & $8.87^{a b}$ & $4.39^{a b}$ & 18 & 60.3 & $12^{b}$ & $110 b$ & $2.6^{\mathrm{b}}$ & $49.0^{d}$ & $44.7^{b}$ \\
\hline 5 & $9.73^{a}$ & $4.16^{\mathrm{ab}}$ & 19 & 60.8 & $30^{\mathrm{a}}$ & $304^{a}$ & $3.2^{\mathrm{ab}}$ & $77.7^{\mathrm{abc}}$ & $57.8^{\mathrm{ab}}$ \\
\hline 10 & $9.53^{a}$ & $4.24^{\mathrm{ab}}$ & 19 & 77.3 & $30.7^{a}$ & $294^{\mathrm{a}}$ & $3.1^{\mathrm{ab}}$ & $68.3^{c d}$ & $68.7^{\mathrm{ab}}$ \\
\hline 20 & $8.73^{a b c}$ & $4.42^{\mathrm{a}}$ & 19 & 86.5 & $29^{a}$ & $315^{a}$ & $3.2^{\mathrm{ab}}$ & $74.0^{\mathrm{bc}}$ & $61.7^{a b}$ \\
\hline
\end{tabular}

Values followed by different alphabets are statistically different at $P \leq 0.05$ 
action between variety and compost in the two pot experiments revealed that growth parameters of the 2 varieties were insignificantly higher in the compost amended pots compared with the control. However, in the second pot experiment, all the parameters were significantly higher in the compost amended pots compared with the control for both varieties (Tables 5). Moreover, values of $\mathrm{N}$ and $\mathrm{P}$ concentrations in plants were similar in the 2 varieties, and concentration of plant $\mathrm{P}$ was similar among the compost rates. However, plants in compost amended pots had significantly higher $\mathrm{N}$ concentrations than those in control, and this trend was particularly observed in the local variety. Field observation reveals that plant height was significantly higher and number of branches was insignificantly higher in the local variety compared with the improved variety in 2014, but the two parameters were marginally higher in the improved variety in 2015. However, the values observed in the compost treatments within each tomato varieties were similar in the two years (Table 9).

\subsection{Response of yield characteristics to treatments}

Table 6 revealed that in the pot experiment, some of the yield characteristics of the local variety were significantly improved compared with the improved variety under an organic production system. Days to flowering and fruiting were significantly less, while number of fruits was significantly higher in the local variety, weight of fruit was however significantly higher in the local variety in the first experiment, but insignificantly higher in the improved variety in the second experiment. Furthermore, values of most of the yield parameters were similar at all the rates of compost amendment. However, plants in the compost amended pots attained fruiting in significantly fewer days than those in the unamended control pots (Table 6). However, soil amendment with $20 \mathrm{t} \mathrm{ha}^{-1}$ compost significantly increased the weight of fruits in the improved variety in the second pot experiment. Compost amendment only improved dry matter yield at $20 \mathrm{t} \mathrm{ha}^{-1}$ in the local variety, but values were similar to the control at other rates. It is important to note that in the 2 varieties, all the other yield parameters were insignificantly improved with increasing rate of compost. Specifically, it was observed in the second pot experiment that amending soil with $5 \mathrm{t}$ $\mathrm{ha}^{-1}, 10 \mathrm{tha}^{-1}$ and $20 \mathrm{tha}^{-1}$ increased the number of fruits in the local variety by $14.4 \%, 63.3 \%$ and $85.5 \%$ respectively, while the improved variety increased by $50 \%, 200 \%$ and $235 \%$ respectively. Furthermore, in the second pot experi- ment, the amendment of soil with $5 \mathrm{t} \mathrm{ha}^{-1}, 10 \mathrm{tha}^{-1}$ and 20 $\mathrm{t}$ ha $\mathrm{a}^{-1}$ increased the weight of fruits in the local variety by $23.8 \%, 40.1 \%$ and $77.4 \%$ respectively and $26.3 \%, 168.3 \%$ and $294.7 \%$ respectively in the improved variety (Table 6). Similar observation was made in the field (Table 9). Shoot dry matter of the two varieties were significantly higher in the plots amended with $20 \mathrm{tha}^{-1}$ of compost compared with the other treatments. In 2014, the number of fruits of the two varieties were significantly increased in plots amended with $20 \mathrm{t} \mathrm{ha}^{-1}$ compared with the other treatments and the weight of fruits in the local variety was significantly increased in plots amended with $20 \mathrm{t} \mathrm{ha}^{-1} \mathrm{com}-$ pared with the other treatments. Also, in 2014, shoot dry matter was insignificantly higher. The number and weight of fruits were significantly higher in the local variety compared with the improved variety, but in 2015, values of the yield parameters were statistically similar among the varieties, although numerically higher in the local variety especially with compost amendment. Yield of tomato was generally higher in 2015 than in 2014, the local variety had a yield increased of over $100 \%$ while improved variety had more than $300 \%$ increases.

\subsection{Correlation between microbial activities, growth and yield of tomato}

Tables $7 \& 8$ revealed high and significant correlations between microbial populations (fungi and bacteria) in soil at the 3 sampling periods (before transplanting, 6 WAT and harvest) and all the growth and yield parameters. Number of days to flowering and fruiting were negatively and significantly correlated to microbial populations especially at 6 WAT, thus suggesting that as microbial populations increased numbers of days to flowering and fruiting decreased. Similarly, microbial biomass N, P and C were significantly correlated to the growth and yield parameters, but the correlation was higher and more consistent at 6 WAT. It was also observed that soil microbial biomass $\mathrm{N}$ and $\mathrm{C}$, at 6 WAT and harvest were highly and consistently correlated with growth parameters; however, they were more consistently correlated with yield parameters at 6 WAT. Enzyme activities (Cellulase, amylase and protease) correlated highly and significantly with growth and yield parameters. The correlation of cellulase activities was more consistent in samples taken before transplanting than the other 2 sampling periods. But, amylase and protease activities more consistently correlated with growth and yield parameters, prior to transplanting and 6 WAT. 
Table 6: Yield characteristics of tomato in pot experiments

\begin{tabular}{|c|c|c|c|c|c|c|c|}
\hline Treatment & $\begin{array}{l}{ }^{2} \text { Dry matter } \\
\text { yield }\left(\mathrm{g} \mathrm{plant}^{-1}\right)\end{array}$ & $\begin{array}{l}{ }^{2} \text { Days to flow- } \\
\text { ering }\end{array}$ & $\begin{array}{l}{ }^{2} \text { Days to } \\
\text { fruiting }\end{array}$ & ${ }^{2}$ No of harvest & $\begin{array}{l}{ }^{2} \text { Number of } \\
\text { fruits }\end{array}$ & $\begin{array}{l}{ }^{2} \text { Weight of fruits } \\
\left(\mathrm{g} \mathrm{plant}^{-1}\right)\end{array}$ & $\begin{array}{l}{ }^{1} \text { Weight of fruits } \\
\text { (g plant }^{-1} \text { ) }\end{array}$ \\
\hline \multicolumn{8}{|l|}{ Varieties } \\
\hline Local & 0.77 & $33.6^{b}$ & $41.6^{b}$ & $4.3^{\mathrm{a}}$ & $12.7 \mathrm{a}$ & 187.7 & $154.5^{\mathrm{a}}$ \\
\hline Improved & 0.72 & $46.0^{\mathrm{a}}$ & $54.4^{\mathrm{a}}$ & $2.25^{\mathrm{b}}$ & $4.4 \mathrm{~b}$ & 200.9 & $112.3^{b}$ \\
\hline \multicolumn{8}{|c|}{ Compost $\left(\mathrm{t} \mathrm{ha}^{-1}\right)$} \\
\hline 0 & 0.80 & 43.5 & $55.5^{\mathrm{a}}$ & 2.7 & 5.5 & 111.7 & 121.8 \\
\hline 5 & 0.78 & 39.7 & $43.2^{b}$ & 3.3 & 9.8 & 176.5 & 125.0 \\
\hline 10 & 0.40 & 37.8 & $45.8^{b}$ & 3.8 & 8.5 & 224.5 & 149.6 \\
\hline 20 & 0.93 & 38.2 & $45.7^{b}$ & 3.3 & 10.3 & 264.5 & 174.5 \\
\hline \multicolumn{8}{|c|}{ Compost $\mathrm{x}$ variety } \\
\hline \multicolumn{8}{|l|}{ Local } \\
\hline 0 & $0.34^{b}$ & $38.0^{\mathrm{abc}}$ & $47.5^{\mathrm{bc}}$ & $3.7^{\mathrm{abcd}}$ & $9.0^{\mathrm{abc}}$ & $138.7^{\mathrm{ab}}$ & 138.6 \\
\hline 5 & $0.72^{\mathrm{ab}}$ & $31.3^{c}$ & $46.2^{\mathrm{bc}}$ & $3.7^{\mathrm{abcd}}$ & $10.3^{\mathrm{ab}}$ & $171.7^{\mathrm{ab}}$ & 140.5 \\
\hline 10 & $0.75^{\mathrm{ab}}$ & $31.3^{c}$ & $44.3^{b c}$ & $5.0^{\mathrm{a}}$ & $14.7^{\mathrm{a}}$ & $194.3^{\mathrm{ab}}$ & 156.7 \\
\hline 20 & $1.28^{\mathrm{a}}$ & $33.4^{b c}$ & $42.6^{c}$ & $4.0^{a b c}$ & $16.7^{\mathrm{a}}$ & $246.0^{\mathrm{ab}}$ & 182.4 \\
\hline \multicolumn{8}{|l|}{ Improved } \\
\hline 0 & $0.57^{b}$ & $49.0^{\mathrm{a}}$ & $55.2^{\mathrm{a}}$ & $1.62^{\mathrm{d}}$ & $2.0^{c}$ & $84.7^{b}$ & 115.0 \\
\hline 5 & $0.63^{\mathrm{ab}}$ & $48.0^{\mathrm{a}}$ & $54.6^{\mathrm{a}}$ & $2.0^{c d}$ & $3.0^{b c}$ & $107.0^{\mathrm{ab}}$ & 119.5 \\
\hline 10 & $0.83^{\mathrm{ab}}$ & $44.3^{\mathrm{ab}}$ & $51.4^{\mathrm{bc}}$ & $2.7^{b c d}$ & $6.0^{b c}$ & $277.3^{\mathrm{ab}}$ & 116.8 \\
\hline 20 & $0.84^{\mathrm{ab}}$ & $42.7^{\mathrm{abc}}$ & $49.2^{\mathrm{bc}}$ & $2.7^{\mathrm{bcd}}$ & $6.7^{\mathrm{bc}}$ & $334.7^{\mathrm{a}}$ & 117.8 \\
\hline
\end{tabular}

Values followed by different alphabets are statistically different at $P \leq 0.05$

$1=$ value of parameter in the first pot experiment

$2=$ values of parameter in the second pot experiment

\section{Discussion}

\subsection{Soil microbial activities}

The observed results indicated that microbial activities measured in this study; as microbial population, biomass $\mathrm{N}, \mathrm{P}$ and $\mathrm{C}$ as well as activities of cellulases, amylases and proteases contributed significantly to the growth and yield of tomato in an organic system. The observed increase in soil microbial populations and activities could be attributed to the stimulation of Zymogenous microorganisms and incorporation of exogenous microorganisms as a result of soil amendment with compost (Scaffers 2000; Lori et al. 2017). Because microorganisms derive their energy and nutrients from the soil environment, incorporation of organic material into the soil usually lead to rapid increases in their numbers and activities. Stamenov et al. (2018) reported that soil devoted to organic production had greater numbers of amino heterotrophs, total bacteria, actinomycetes and fungi. The higher microbial populations observed in the rhizosphere of the local variety is probably due to its longer period of cultivation and adaptation to that environment. Robertson and Morgan (1996) observed that history of the experimental soil had a strong influence on microbial population and they, as well as Dick (1992), demonstrated the importance of this in converting from a conventional to an organic production system. The microbial community is positively affected by the amount and quality of organic inputs (Ferreira de Araujo and Jose de Melo 2010), thus, increasing the rate of compost amendment had a positive impact on the soil microbial population. Research has also demonstrated that the build-up of large and active microbial biomass is an important pool of accessible nutrients and it is of paramount importance in an organic system (Tu et al. 2006; Araujo et al. 2009; Ferreira de Araujo and Jose de Melo 2010). Residue quality is frequently determined by the $\mathrm{C} / \mathrm{N}$ ratio (Young 1997). In this study, the compost used as the soil amendment has a $\mathrm{C} / \mathrm{N}$ ratio of 9.4 , thus favouring the decomposition and mineralization of nutrients. These processes are central functions in organic production systems, and they are mediated by soil microorganisms (Dick et al. 2001; Ferreira de Araujo and Jose de Melo 2010).

The increase in soil microbial biomass $\mathrm{N}, \mathrm{P}$ and $\mathrm{C}$ due to increased rate of compost application could be attributed to higher contents of these nutrients in the labile organic pool (Campbell 1991a\&b). The labile organic $\mathrm{N}$ pool is partially related or controlled by microbial biomass $\mathrm{N}$, microbial activity and ultimately $\mathrm{N}$ mineralization (Parton et al. 1987; Dick et al. 2001; Ferreira de 


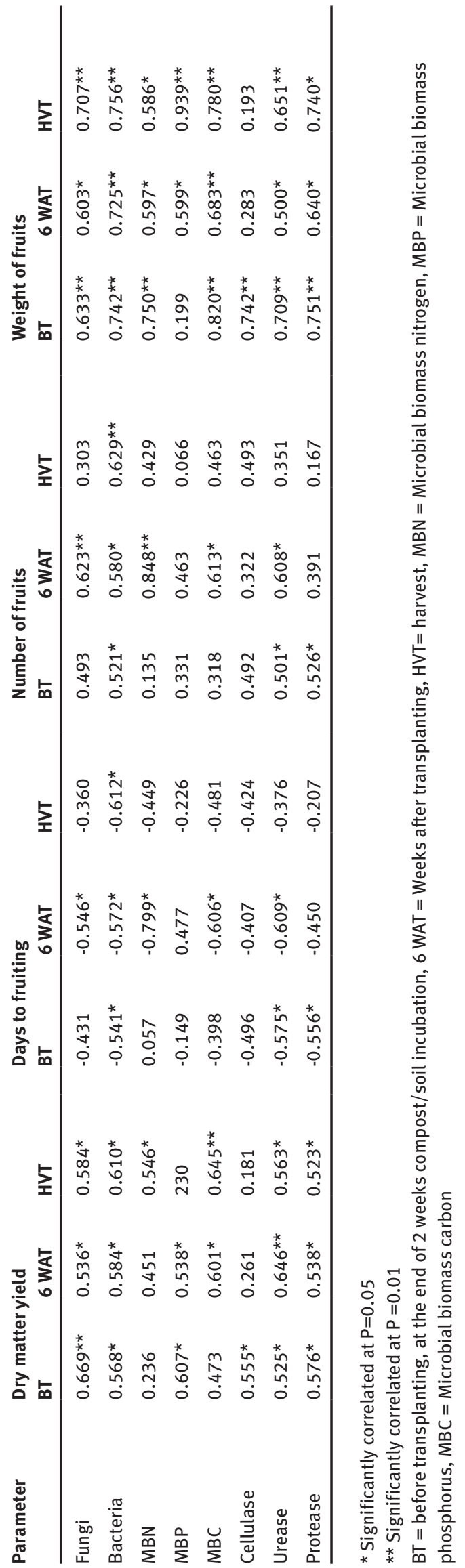


Table 9: Growth and yield characteristics of tomato varieties in response to field application of 3 rates of compost in 2014 and 2015

\begin{tabular}{|c|c|c|c|c|c|c|c|c|c|c|}
\hline \multirow[t]{2}{*}{ Treatment } & \multicolumn{2}{|c|}{$\begin{array}{l}\text { Number of branches/ } \\
\text { plant }\end{array}$} & \multicolumn{2}{|c|}{ Plant height (cm) } & \multicolumn{2}{|c|}{ Dry matter yield (g plant $\left.{ }^{-1}\right)$} & \multicolumn{2}{|c|}{$\begin{array}{l}\text { Number of fruits per } \\
\text { plant }\end{array}$} & \multicolumn{2}{|c|}{$\begin{array}{l}\text { Weight of fruits ( } t \\
h^{-1} \text { ) }\end{array}$} \\
\hline & 2014 & 2015 & 2014 & 2015 & Shoot & Root & 2014 & 2015 & 2014 & 2015 \\
\hline \multicolumn{11}{|c|}{ Improved variety } \\
\hline $0 \mathrm{tha}^{-1}$ & 26 & 30 & 60.8 & 67.0 & 16.4 & 3.3 & 3.0 & 9.0 & 0.5 & 4.6 \\
\hline 10 t ha $^{-1}$ & 35 & 49 & 55.5 & 77.0 & 15.4 & 2.9 & 3.0 & 8.0 & 0.9 & 4.1 \\
\hline 20 t ha $^{-1}$ & 31 & 60 & 54.2 & 90.0 & 26.2 & 4.6 & 4.0 & 9.0 & 1.0 & 6.2 \\
\hline Mean & 30.7 & 46.3 & 56.8 & 78.0 & 19.3 & 3.6 & 3.0 & 8.6 & 0.8 & 5.0 \\
\hline \multicolumn{11}{|l|}{ Local variety } \\
\hline $0 \mathrm{ha}^{-1}$ & 47 & 39 & 73.0 & 70.0 & 18.8 & 2.0 & 4.0 & 7.0 & 1.7 & 4.6 \\
\hline $10 \mathrm{ha}^{-1}$ & 42 & 40 & 71.3 & 74.0 & 21.3 & 3.6 & 4.0 & 9.0 & 2.0 & 5.9 \\
\hline $20 \mathrm{ha}^{-1}$ & 46 & 45 & 71.6 & 88.0 & 30.5 & 4.3 & 5.0 & 10.0 & 3.5 & 6.2 \\
\hline Mean & 45 & 41.1 & 72.0 & 77.3 & 23.5 & 3.3 & 4.3 & 9.0 & 2.4 & 5.1 \\
\hline LSD & NS & NS & 9.164 & 7.01 & 6.2 & NS & 0.967 & NS & 0.79 & NS \\
\hline
\end{tabular}

NS = Not statistically different at $P \leq 0.05$

Values followed by different alphabets are statistically different at $P \leq 0.05$

Araujo and Jose de Melo 2010). Therefore, the build-up of soil microbial biomass $\mathrm{N}$ is thought to be an important determinant of $\mathrm{N}$ release synchrony and this is probably one of the reasons for the suggestion that soil microbial biomass is an index of the rate of organic N decomposition and mineralization (Ayanaba et al. 1976; Alegre et al. 1985). Similarly, phosphorus mineralization is controlled in part by the availability of phosphatase enzymes produced by soil microorganisms and plant roots (Tabatabai 1994). Microbial biomass $P$ was observed to increase in soil after addition of livestock manures (He et al. 1997; Leytem et al. 2005) or plant residues (Nziguheba et al. 2000; Kouno et al. 2002). Takeda et al. (2009) noted that microbial biomass $\mathrm{P}$ increased due to greater $\mathrm{C}$ addition through rye incorporation than rape seed incorporation. It has also been suggested that $C$ additions stimulates microbial activity thereby enhancing the overall assimilation of P by microorganisms (Hedley et al. 1982; Bunemann et al. 2004). Furthermore, microbial biomass $C$ and fungal growth were reported to be stimulated by inclusion of two legumes in a rotation than inclusion of only one legume (Granatstein et al. 1987; Robertson and Morgan 1996) and this was attributed to $\mathrm{C}$ and $\mathrm{N}$ returned to the soil in residues. However, the reduction in microbial biomass $\mathrm{N}, \mathrm{P}$ and $\mathrm{C}$ in the course of tomato cultivation could be attributed to plant uptake, which reduced the amount of nutrients available for continuous microbial assimilation. Macklon et al. (1997) noted that organic P compounds of microbial origin are readily hydrolysable and can become available for plant uptake. It could also be due partly to depletion of readily decomposable materials from the soil.
The higher activities of cellulases and protease at the rhizosphere of the local tomato variety may be attributed to varietal difference, some enzymes are produced by both soil microorganisms and plant roots (Tabatabai 1994). Due to the depletion of substrates as growth and development of tomato continues, enzyme activities also reduced. This is because some of the enzymes are adaptive and are produced due to the presence of their substrates (Paul and Clarke 1988). Soil amendment with compost probably stimulated soil microorganisms to produce higher levels of cellulases, amylase and protease and this persisted throughout the live cycle of tomato. However as microbial activities declined, enzyme activities also declined. Brockett et al. (2011) also observed that reduction in microbial biomass or shifts in the abundance of the various microbial groups could lead to changes in enzyme activities. Takeda et al. (2009) also made a similar observation on phosphatase activity and suggested that functionality of the phosphatase enzyme might have been maintained through association with soil components (Leprince and Quiquampoix 1996).

\subsection{Nutrient status of soil}

Consequent to higher microbial activities in compost amended pots, the level of soil nitrogen, phosphorus and organic carbon improved. Roots of the local variety probably produced higher amounts of substrates containing hydrolysable $\mathrm{P}$, thereby giving higher $\mathrm{P}$ at its rhizosphere than was observed in the improved variety. Maeder et al. 
(2002) indicated a higher microbial activity resulting in a higher capacity to cleave protein and organic P, thus leading to enhanced soil fertility and higher biodiversity in organic plots. Furthermore, mineralization of these nutrients from compost, increased up until before transplanting for $\mathrm{N}$ and $\mathrm{P}$, and harvest for $\mathrm{C}$. This observation is supported by the higher levels of N, P and C in the microbial tissue, because these nutrients in organic fertilizers must pass through the microbial pool before they are made available for plant uptake (Alexander 1977). In this experiment, soil nutrients were first measured 2 weeks after compost amendment, but before transplanting of tomato. Earlier findings showed that most $\mathrm{C}$ and $\mathrm{N}$ mineralization from organic materials occur in the first few weeks after application to soil (Jenkinson and Ayanaba 1977; Amato et al. 1987), Studies have also shown that $P$ assimilated by microorganisms after addition of manures was partly derived from $\mathrm{P}$ in less plant available forms and organic $\mathrm{P}$ compounds of microbial origin are readily hydrolysable and can become available for plant uptake (Macklon et al. 1997; Maeder et al. 2002; Bunemann et al. 2004; Takeda et al. 2009).

In organic farming systems, the management of soil organic matter is crucial to maintaining the fertility of the soil. Because mineral fertilizers must be avoided, soil fertility management strategies usually include sound management of crop residues and manures, which when composted, is a form of slow-release organic fertilizer. Compost amendment led to an improvement in plant nutrition of macronutrients like $\mathrm{N}, \mathrm{P}$ and $\mathrm{C}$ as observed in this study, as well as micronutrients (Roe et al. 1997). Composted manure has a long-term role in building soil fertility and has been shown to be more effective in building soil microbial biomass and increasing microbial activities (Fließbach and Maeder 2000), thus improving the chemical, biological and physical properties of the soil. This is particularly important in organic production systems, which depend on maximum chemical, biological and physical conditions to be optimally productive.

\subsection{Growth and yield of tomato varieties}

The improved growth and yield in the local variety, as observed in the screen house and field, could be attributed to varietal differences. The local variety was able to mobilize nutrients from compost for its assimilation because it interacted with higher populations of the soil microbes. The higher microbial populations at the rhizosphere of the local variety contributed significantly to its growth and yield, and improved the soil quality (Babalola et al.
2012). In contrast, the improved variety was developed to perform optimally in the presence of high and sufficient levels of available nutrients, usually applied as mineral fertilizers. Compost amendment also improved the yield of tomato, this is a consequence of increased availability of nutrients in compost amended pots; $\mathrm{N}$ and $\mathrm{P}$ concentration in plant tissue increased, leading to increase in growth and development of tomato. Heitkamp et al. (2011) noted that labile soil organic matter pools were significantly related to rates of farmyard manure and to crop yields. Similarly, Tejeda et al. (2008) observed higher microbial biomass $\mathrm{C}$, enzyme activities and crop cover in plots amended with composted plant residues. Therefore, they concluded that since soil enzymatic activities are responsible for important cycles such as $\mathrm{C}, \mathrm{N}, \mathrm{P}$ and $\mathrm{S}$, plant cover increased significantly when a higher dose of composted plant residues was applied to soil.

In addition to supplying nutrients, composts have also been shown to reduce disease severity (Kim et al. 1997; Abawi and Widmer 2000; Popoola et al. 2011), and this could have contributed to the improved yield observed in tomato varieties. Hence soil amendment with compost in an organic production system can supply nutrients, reduce diseases, check weeds and pests, all these are of crucial concern in an organic system. Also, because organic production promotes systems that are conscious of environmental sustenance, composting of manure will conserve manure nutrients for both economic and environmental benefits.

Correlation analysis showed that soil microbiological activities at the vegetative growth stage (6 WAT) contributed more significantly to growth and yield of tomato. This is because the plants require high amounts of nutrient for growth and development at this stage. Thus high microbial activities at the vegetative growth stage are likely to improve nutrient availability at this critical stage of crop need and development. Gunapalaa and Scow (1998) also observed significantly positive correlation of mineral $\mathrm{N}$ with tomato growth and yield in organic systems. Yields of tomato varieties increased in compost amended soil due to enhanced biological activities, which led to improved nutrient uptake. Stoffella and Graetz (1996) reported higher total and early marketable yields as well as higher fruit size in plots amended with compost compared with the control. Identifying the growth stage when compost amendment is likely to produce highest benefit is of crucial importance in an organic production system, because the system relies on strategies that protect soil from degradation and strives towards a continuous maintenance of soil fertility. 
While practices like crop rotation and crop residue management are adopted for managing soil fertility, additional nutrients can be supplied from composts at critical growth stages to fully meet the high nutrient requirement of crops at those stages. The increase in tomato yield in 2015 over 2014 in both varieties is attributed mainly to improvement of soil quality due to applications of compost for two planting seasons. Babalola et al. (2012) reported that application of 10 to $20 \mathrm{t} \mathrm{ha}^{-1}$ of compost to soil, improved soil chemical, physical and biological conditions. They demonstrated that MBN, MBP, MBC and SOC increased up to 1 year after amendment, while bulk density significantly decreased by $4.8 \%$, aggregate stability improved by $15.7 \%$, and total porosity increased by $2.8 \%$ after 2 years of amendment, but hydraulic conductivity increased insignificantly. The residual effect of 2014 compost application led to more than $100 \%$ yield increase in the local variety and over $300 \%$ increase in the improved variety in 2015. More favourable biotic and abiotic conditions such as higher rainfall and lower disease incidence could also have contributed to the yield increase.

\section{Conclusion}

The activities of microorganisms as measured by population, biomass N, P and C, cellulase, amylase and protease activities increased due to compost application. Increased microbial activities led to high releases of nutrients from compost, thereby improving nutrients uptake, growth and yield of tomato varieties. Increasing the rate of compost from 5 to $20 \mathrm{t} \mathrm{ha}^{-1}$ significantly increased microbial activities leading to increase in tomato yield. Therefore, microbial activities could be optimized at $20 \mathrm{tha}^{-1}$ to increase the growth and development of tomato and thus giving higher yield. Moreover, the rhizosphere of the local tomato variety had a more favourable influence on microbial activities, thus improving its nutrient availability and uptake, leading to higher growth and yield.

Acknowledgement: The author wishes to acknowledge the assistance of Misses F.C Oladeji, and A.T Osungade for their assistance in data collection.

Conflict of interest: Authors declare no conflict of interest.

\section{References}

[1] Abawi G.S., Widmer T.L., Impact of soil health management practices on soilborne pathogens, nematodes and root diseases of vegetable crops. Applied Soil Ecology, 2000, 15, 37-47

[2] Acharya C.L., Bishnoi S.K., Yaduvanshi H.S., Effect of long-term application of fertilisers, and organic and inorganic amendments under continuous cropping on soil physical and chemical properties in an Alfisol. Indian Journal of Agricultural Sciences, 1988, 58, 509-516

[3] Alegre J.C., Cassel D.K., Bandy D.E., Sanchez P.A., Effects of land clearing on soil properties of an Ultisol with subsequent crop production in Yurimaguas, Peru. In R. Lai et al. (ed) Rotterdam, the Neterlands, 1985, 167-177

[4] Alexander M., Introduction to Soil Microbiology $2^{\text {nd }}$ Ed. John Wiley \& Sons Inc. New York 1977, 225-250

[5] Altieri M.A., The ecological role of biodiversity in Agroecosystems. Invertebrate Biodiversity as Bioindicators of Sustainable Landscapes, 1999, 74, 19-31, DOI: 10.10161/ B978-0-444-50019-9.50005-4

[6] Amato M., Ladd J.N., Ellington A., Ford G., Mohaney J.E., Taylor A.C., Walsgott D., Decomposition of plant material in Australian soils. IV. Decomposition in situ of ${ }^{14} \mathrm{C}$ and $15 \mathrm{~N}$ legumes and wheat materials in a range of Southern Australian Soils. Australian Journal of Soil Research, 1987, 25, 95-105.

[7] Anderson J.P.E., Domsch K.H, Mineralisation of bacteria and fungi in chloroform-fumigated soils. Soil Biol. Biochem., 1978a, 10, 207-213

[8] Anderson J.M, Ingram J.S.I., Tropical soil biology and fertility. A handbook of methods ( $2^{\text {nd }} e d$.) CAB International, 1993, 68-69

[9] Araujo A.S.F., Leite L.F.C., Santos V.B., Carneiro R.F.V., Soil microbial activity in conventional and organic agricultural systems. Sustainability, 2009, 1(2), 268-276, DOI: doi. org/10.3390/su1020268

[10] Atkinson D., Watson C.A., The research needs of organic agriculture-distinct or just part of agricultural research? The BCPC Conference-Pests and Diseases, 2000, 151-158

[11] Ayanaba A., Tuckwell S.B., Jenkinson D.S., The effect of clearing and cropping on the organic reserves and biomass of tropical forest soils. Soil Biol. Biochem., 1976, 8, 519-525

[12] Babalola O.A., Adesodun K.J., Olasantan F.O., Adekunle A.F., Response of some soil chemical, biological and physical properties to short-term compost amendment. Int. J. Soil Sc., 2012, 7(1), 28-38, Doi: 10.3923/ijss.2012.28.38

[13] Barea J.M., Azcon R., Azcon-Aguilar C., Mycorrhizal fungi and plant growth promoting rhizobacteria. In: Verma A, Abbot L, Werner D, Hampp R (eds.) Plant surface microbiology. Heidelberg, Germany: Springer-Verlag, 2004, 195-212

[14] Barea J.M., Poso J.M., Azcon R., Azcon-Aguilar C., Microbial co-operation in the rhizosphere. J. Expl. Botany, 2005, 1-18 Doi: $10.1093 /$ jxb/eri197

[15] Beralseld P., Method in enzymology. In: Culuwick IS, Kaplum N Academic Press, 1955, 149

[16] Bray R.H., Kurtz L.T., Determination of total, organic and available forms of phosphorus in soils. Soil Sci., 1945, 59, $39-45$ 
[17] Bremner J.M., Nitrogen-Total. IN: Methods of Soil Analysis Part 3. Chemical methods. Sparks DL (Ed) ASA SSSA, Madison, WI, 1996, 1085-1121

[18] Brockett B.F.T., Prescott C.E., Grayston S.J., Soil moisture is the major factor influencing microbial community structure and enzyme activities across seven biogeoclimatic zones in western Canada. Soil Biol. Biochem., 2011, 44, 9-20 Doi: 10.1016/j.soilbio.2011.09.003

[19] Bunemann E.K., Steinebrunner F., Smithson P.C., Frossard E., Oberson A., Phosphorus dynamics in a highly weathered soil as revealed by isotopic labeling techniques. Soil Sc. Soc. Am J, 2004, 68, 1645-1655

[20] Campbell C.A., Biederbeck V.O., Zentner R.P., Lafond G.P., Effect of crop rotations and cultural practices on soil organic matter, microbial biomass and respiration in a thin Black Chernozem. Canadian J of Soil Sci., 1991a, 71, 363-76

[21] Campbell C.A, Bowren K.E, Schnitzer M., Zentner R.P., Townley-Smith L., Effect of crop rotation and fertilization on soil organic matter and some biochemical properties of a thick Black Chernozem. Canadian J. of Soil Sci., 1991b, 71, 377-387

[22] Cochran W.G., Estimation of bacteria densities by means of the "most probable number" Biometrics, 1950, 6, 105-116

[23] Cook R.J., Plant health and sustainability of agriculture, with special reference to disease control by beneficial microorganisms. Biological Agriculture and Horticulture, 1986, 3 , 211-232

[24] DeVleechauwer D.O., Verdonock P., VanAssche P., Phytotoxicity of refuse compost. Biocycle, 1981, 22, 44-45

[25] Dick R.P., A Review: long-term effects of agricultural systems on soil biochemical and microbial parameters. Agric. Ecosystems Environ., 1992, 40, 25-36, DOI: 10.1016/B978-0444-89390-1.50005-6

[26] Dick R.P., Yamoah C., Diack M., Badiane A.N., Soil microorganism and soil fertility. In Sustaining Soil fertility in West Africa. Soil Sci. Soc. Am \& Am Soc. Agron SSSA special publication, 2001, 58, 23-43

[27] Ferreira de Araujo A.S., Jose de Araujo W., Soil microbial biomass in organic farming system. Ciencia Rural, 2010, 40(11), 3-8, Doi: dx.doi.org/10.1590/ s0103-847820005000192

[28] Fließbach A., Maeder P., Microbial biomass and size-density fractions between soils of organic and conventional agriculture systems. Soil Biol. Biochem., 2000, 32, 757-768

[29] Garcia-Ruiz R., Ochoa V., Hinojosa M.B., Carreira J.A., Suitability of enzyme activities for monitoring of soil quality improvement in organic agricultural systems. Soil Biol. Biochem., 2008, 40(9), 2137-2145, DOI: doi.org/10.1016/j. soilbio.2008.03.023

[30] Granatstein D.M., Bezdicek D.F., Cochran V.L., Elliot L.F., Hammel J., Long-term tillage and rotation effects on soil microbial biomass, carbon and nitrogen. Biol. Fert. Soils, 1987, 5, 265-270

[31] Grantzau E., Bark mulch for weed control in cut-flower perennials Zlerpflzenbau, 1987, 27,805-806

[32] Gunapalaa N., Scow K.M., Dynamic of soil microbial biomass and activity in conventional or organic farming systems. Soil Biol. Biochem., 1998 30(6), 805-816, DOI: doi.org/10.1016/ S0038-0717(97)00162-4
[33] Haynes R.J., Naidu R., Influence of lime, fertilizer and manure applications on soil organic matter content and soil physical conditions: a review. Nutrient cycling in agroecosytems, 1998, 51(2), 123-137, doi.org/10.1023/A:1009738307837

[34] He Z.L., Wu J., O’Donnell A.G., Syers J.K., Seasonal responses in microbial biomass carbon, phosphorus and sulphur in soils under pasture. Biol. Fert. Soils, 1995, 24, 421-428

[35] Hedley M.J., Stewart J.W.B., Chauhan B.S., Changes in inorganic and organic soil phosphorus fractions induced by cultivation practices and by laboratory incubations. Soil Sci. Soc. Am. J., 2001, 46, 970-976

[36] Heitkamp F., Raupp J., Ludwig B., Soil organic matter pools and crop yields as affected by the rate of farmyard manure and use of biodynamic preparations in a sandy soil Org. Agr., 2011, 1, 111-124, Doi: 10.007/s13165-011-0010-7

[37] Hoitnik H.A.J., Fahey P.C., Basis for the control of soil-borne plant pathogens with composts. Annual Review of Phytopathology, 1986, 24, 93-144

[38] Jenkinson D.S., Powlson D.S., The effect of biocidal treatments on metabolism in soil. V A method for measuring soil biomass. Soil Biol. Biochem., 1976, 8, 209-213

[39] Jenkinson D.S., Ayanaba A., Decomposition of carbon-14 labelled plant material under tropical conditions. Soil Sci. Soc. Am. J., 1977, 41, 912-915

[40] Juo A.S.R., Moormen F.R., Maduakor H.O., Forms and pedogenic distribution of extractable $\mathrm{Fe}$ and $\mathrm{Al}$ in selected soils of Nigeria. Geoderma, 1974, 11, 167-179

[41] Kim K.D., Nemec S., Musson G., Effects of composts and soil amendments on soil microflora and phytophthora root and crown rot of bell pepper. Crop Protection, 1997, 16, 165-172

[42] Kouno K., Wu J., Brookes P.C., Turnover of biomass C and P in soil following incorporation of glucose or ryegrass. Soil Biol. Biochem., 2002, 34, 617-622

[43] Latif M.A., Mehuys G.R., Mackenzie A.F., Alli I., Faris M.A., Effects of legumes on soil physical quality in a maize crop. Plant and Soil, 1992, 140, 15-23

[44] Leprince F., Quiquampoix H., Extracellular enzyme activity in soil: effect of $\mathrm{pH}$ and ionic strength on the interaction with montmorillonite of two acid phosphatases secreted by the ecto-mycorrhiza fungus Hebeloma cylindrosporum. Eur. J. Soil Sci., 1996, 47, 511-522

[45] Leytem A.B., Turner B.L., Raboy V., Peterson K.L., Linking manure properties to phosphorus solubility in calcareous soils: Importance of the manure carbon to phosphorus ratio. Soil Sci. Soc. Am J., 2005, 69, 1516-1524

[46] Lori M., Symnaczik S., Maeder P., De Deyn, Gattinger A., Organic farming enhances soil microbial abundance and activity - A meta - analysis and meta - regression. PLosONE, 2017, 12(7), DOI: doi-org/10.1371/journal-pone.0180442

[47] Macklon A.E.S., Macklon S.J., Grayston S.J., Shand C.A., Sim A., Sellars S., Ord B.G., Uptake and transport of phosphorus by Agrostis Caillaris seedlings from rapidly hydrolysed organic sources extracted from ${ }^{32} \mathrm{P}$ bacterial cultures. Plant and Soil, 1997, 190, 163-167

[48] Maeder P., Fliessbach A., Dubois D., Gunst L., Fried P., Niggli U., Soil fertility and biodiversity in organic farming. Science, 2002, 296(5573), 1694-1697, DOI: doi.org/10.1126/ science.1071148

[49] McKinley V.L., Vestal J.R., Eralp E.A., Microbial activity in composting. Biocycle,1885, 26, 39-43 
[50] Murphy J., Riley J.P., A modified single solution method for determination of phosphate in natural water. Anal. Chem. Acta., 1962, 27, 31-36

[51] Nannipieri P., Ascher J., Ceccherini M.T., Landi L., Pietramellara G., Renella G., Microbial diversity and soil functions. Eur. J. Soil Sci., 2003, 54, 655-670

[52] Nelson D.W., Summers L.E., Total Carbon, Organic Carbon and Organic Matter. In: Methods of Soil Analysis. Part 3.Chemical Methods. No. 5, Sparks, D. L. (Ed.), ASA and SSSA, Madison, WI, 1996, 61-1010

[53] Nziguheba G., Mercckx R., Palm C.A., Rao M.R., Organic residues affect phosphorus availability and maize yields in a Nitisol of western Kenya. Biol. Fert. Soils., 2000, 32, 328-339

[54] Parton W.J., Schimell D.S., Cole C.V., Ojima D.S., Analysis of factors affecting soil organic matter levels in Great Plains grassland. Soil Sci. Soc. Am. J., 1987, 51, 1173-1179

[55] Paul E.A., Clarke F.E., Soil Microbiology and Biochemistry, (2nd ed.). Academic Press, San Diego, New York, Boston, London, Sydney, Tokyo, Toronto, 1988, 1-275

[56] Popoola A.R., Ganiyu A.S., Babalola O.A., Ayo-John E.I., Effects of tillage methods, varieties and compost amendments on bacterial leaf spot, leaf speck and fruit yield of two tomato varieties. Nigerian Journal of Plant Protection, 2011, 25(1), 127-138

[57] Powlson D.S., Brookes P.C., Christensen B.T., Measurement of soil microbial biomass provides an early indication of changes in total soil organic matter due to straw incorporation. Soil Biol. Biochem., 1987, 19, 159-164

[58] Reeves T.G., Ellington A., Brooke P.C., Effects of lupin-wheat, rotations on soil fertility, crop disease and yields. Australian Journal of Experimental Agriculture and Animal Husbandry, 1984, 24, 595-600

[59] Robertson F.A., Morgan W.C., Effect of management history and legume green manure on soil microorganisms under 'organic' vegetable production. Aust. J. Soil Res., 1996, 34, 427-440

[60] Roe N.E., Stofella P.J., Graetz D.A., Compost from various municipal waste feedstocks affects vegetable crops II. Growth, yields, and fruit quality. Journal of American Society of Horticultural Science, 1997, 122, 433-437

[61] Roe N.E., Stoffella P.J., Bryan H.H., Utilization of MSW compost and other organic mulches on commercial vegetable crops. Compost Science Utilization, 1993, 1, 73-84

[62] Rynk R., (Ed.). On farm-Composting Handbook. Northeast Regional Agricultural Engineering Services, Coop. Ext., NRAES-54 Ithaca, USA, 1992

[63] SAS SAS procedure guide (version 6), 3rd Ed. SAS Institute Inc. Gary, North Caroline. USA, 1989

[64] Scaffers A.P., In situ annual nitrogen mineralization predicted by simple soil properties and short-period field incubation. Plant and Soil, 2000, 221, 205-219

[65] Sivapalan A., Morgan W.C., Franz P.R., Monitoring populations of soil microorganisms during a conversion from a conventional to an organic system of vegetable growing. Biological Agriculture and Horticulture, 1993, 10, 9-27
[66] Stamenov D., Duric S., Jafar T.M., Ciric V., Manojlovic M., Microbiological activity in soil of various agricultural crops in organic production. Contemporary agriculture, 2018, 67(1), 34-39, DOI: doi.org/10.2478/contagri-2018-0005

[67] Stockdale E.A., Lampkin N.H., Hovi M., Keatinge R., Lennartsson E.K.M., MacDonald D.W., et al. Agronomic and environmental implications of Organic Farming Systems, Advances in Agronomy, 2001, 70, 261-327

[68] Stoffella P.J., Graetz D.A., Sugarcane filtercake compost influence on tomato on tomato emergence, seedling growth, and yield. In: The Science of Composting, Part 2, Debertoldi et al. (Eds.) Black Academic and Professional, New York, USA, 1996

[69] Sommers S.G., Kjellerup V., Kristjansen O., Determination of total ammonium nitrogen in pig and cattle slurry: Sample preparation and analysis, Acta Agric. Scarzd. Section B, 1992, 146-151

[70] Tabatabai M.A., Soil enzymes In: Weaver et al. (eds) Methods of Soil Analysis. Part 2 Microbiological and Biochemical properties. SSSA Books Series, 1994, 5, 775-833

[71] Takeda M., Nakamoto T., Miyazawa K., Murayama T., Okada H., Phosphorus availability and soil biological activity in an Andosol under compost application and winter cover cropping. Applied Soil Ecology, 2009, 42, 86-95, Doi: 10.1016/japsoil.2009.02.003

[72] Takeda Y., Hizukuri, Sweet potato beta-amylase Biochem. Biophys. Acta., 1969,185-469

[73] Tejeda M., Hernandez M.T., Garcia C., Soil restoration using composted residues: Effects on soil properties. Soil and Tillage Research, 2008, 102, 109-117, Doi: 10.1016/ jstill.2008.08.004

[74] Tu C., Ristiano J.B., Hu S., Soil microbial biomass and activity in organic tomato farming system: effects of organic inputs and straw mulching. Soil Biol. Biochem., 2006, 38(2), 247-255, DOI: 10.1016/j.soilbio.2005.05.002

[75] Watson C.A., Bengtsson H., Ebesvik M., Loes A.K., Salomon E., Schroder J., et al. A review of farm-scale nutrient budgets for organic farms as a tool for management of soil fertility. Soil Use and Management, 2002, 18, 261-273.

[76] Wahua T.A.T., Linear regression and correlation. In: Applied statistics. Africa-Link books, Aba, Nigeria, 1999, 250-288

[77] Young A., Agroforestry for soil management CAB International, Oxon, 1997, 122-126

[78] Zibilske L.M., Composting of organic wastes In Sylvia DM, Hartel PG, Fuhrmann JJ, Zuberer DA (Eds.) Principles and applications of soil microbiology Pearson Prentice Hall Upper Saddle River, NJ 07458. ISBN 0130941174, 2005, 587-606

[79] Zuberer D.A., Recovery and enumeration of viable bacteria. In Weaver RW, Angle S, Bottomly P, Bezdicek D, Smith S, Tabatabai A, Wollum A (Eds), Methods of Soil analysis, Part 2. Microbiology and Biochemical Properties. Soil Science Society of America Books Series, No 5. Madison Wis., 1994 